\title{
Peningkatan Mutu Layanan Wisata Kampung Homestay Desa Samiran, Selo, Boyolali Melalui Pelatihan Bahasa Prancis
}

\section{Hayatul Cholsy, Aprillia Firmonasari}

Prodi Sastra Prancis, Fakultas Ilmu Budaya, Universitas Gadjah Mada

Korespondensi: cholsy-h@ugm.ac.id

Tim Pengabdian kepada Masyarakat:

Wening Udasmoro, Suryo Baskoro, Ali Shahab, Subiyantoro, Wiwid Nurwidyohening, Cartalyna Napitupulu, Sajarwa, Wulan Tri Astuti, Siti Rahayu

\begin{abstract}
French for tourism training especially for tourism practitians and homestay owners is a community service program carried out by French Literature program in Samiran Tourism Village, Selo, Boyolali. The program involved all the French Literature's civitas academica, lecturers, students, administrative staff and the community of Samiran. This program aims to practice practical French for tourism and to translate the tourism village website into French for expanding the marketing network for francophone community. In the future, this program can be expected to increase the welfare of the community by the presence of foreign tourists especially from francophone countries.
\end{abstract}

Keywords: French for tourism training, Samiran Tourism Village, francophone

\begin{abstract}
Abstrak
Program pembelajaran bahasa Prancis bagi pelaku pariwisata merupakan program pengabdian kepada masyarakat yang dilakukan oleh Program Studi Sastra Prancis FIB UGM di Desa Samiran, Kecamatan Selo, Kabupaten Boyolali. Kegiatan ini melibatkan civitas academica, yaitu dosen, mahasiswa, dan staf administrasi di lingkungan Prodi Sastra Prancis dan masyarakat Desa Samiran, Kecamatan Selo, Boyolali. Kegiatan ini bertujuan melatih bahasa Prancis praktis bagi pelaku pariwisata dan penerjemahan website desa wisata ke dalam bahasa Prancis untuk memperluas jaringan pemasaran bagi masyarakat francophone. Kegiatan ini ke depan diharapkan dapat meningkatkan kesejahteraan masyarakat desa tersebut dengan hadirnya wisatawan mancanegara, terutama dari negara-negara francophone.
\end{abstract}

Kata kunci: pembelajaran bahasa Prancis pariwisata, Desa Wisata Samiran, francophone

\section{Pendahuluan}

Pesona keindahan Gunung Merapi dan Merbabu akan terus ada dalam setiap memori masyarakat Indonesia dengan gambar pemandangan sawah yang dilatarbelakangi oleh sepasang gunung. Keindahan alam kedua gunung tersebut dapat dinikmati dari daerah di antara kedua gunung tersebut, seperti di Kecamatan Selo, Kabupaten Boyolali, Jawa Tengah. Kecamatan Selo merupakan daerah transit bagi para pendaki sebelum 
mendaki gunung, terutama Gunung Merapi. Oleh karena itu, Kecamatan Selo selalu ramai dikunjungi wisatawan, baik lokal maupun mancanegara, terutama yang akan mendaki Gunung Merapi.

Tidak hanya wisatawan yang akan mendaki gunung yang singgah di Selo, tetapi mereka yang ingin menikmati keindahan alam dan udara yang sejuk di kawasan tersebut juga tertarik untuk mengunjunginya. Hal ini terbukti dengan melonjaknya angka wisatawan yang berkunjung ke kawasan tersebut sepanjang tahun 2017 (Aditya, 2017). Pelonjakan tersebut karena Desa Samiran menawarkan keindahan pemandangan Gunung Merapi dan Merbabu, udara yang sejuk, tradisi budaya yang masih kental, banyaknya kekayaan pertanian, serta adanya perbaikan layanan akses jalan, sarana, dan prasarana. Di samping itu, letak Kecamatan Selo sangat strategis, yaitu berada di persimpangan antara Semarang, Solo, dan Yogyakarta. Kelebihan-kelebihan itulah yang menyebabkan Kecamatan Selo menjadi salah satu alternatif daerah wisata terbaik di Jawa Tengah.

Pemerintah dan warga setempat melihat bahwa kawasan mereka sangat berprospek untuk dijadikan sebagai kawasan wisata dengan pengelolaan yang lebih profesional, yang berbasis pada Community Based Tourism Development (Tiono, 2017), yaitu mengedepankan partisipasi aktif masyarakat setempat untuk mengelola tempat wisata. Saat ini, warga setempat mulai berbenah dengan menyediakan kawasan tempat tinggal mereka untuk dijadikan sebagai homestay atau hunian sederhana bagi para wisatawan, terutama di Desa Samiran, Kecamatan Selo. Jumlah homestay sudah mencapai sekitar 31 rumah dan kawasan tersebut menjadikan desa wisata Samiran menjadi salah satu kampung homestay unggulan di Boyolali. Selain homestay, segala fasilitas yang berhubungan dengan pelayanan para wisatwan juga mulai digiatkan oleh pemerintah setempat dan dibantu pula oleh LSM serta CSR perusahaan yang peduli akan kesejahteraan masyarakat desa, baik yang berhubungan dengan sarana dan prasarana maupun SDM-nya.

Peningkatan kemampuan SDM menjadi hal yang penting untuk diperhatikan karena bagaimanapun juga peran SDM sangat besar dalam bidang pariwisata. Oleh karena itu, Prodi Sastra Prancis, Fakultas Ilmu Budaya, Universitas Gadjah Mada menunjukkan kepeduliannya dengan berpartisipasi dalam persiapan peningkatan kemampuan SDM di bidang pariwisata. Bentuk partisipasi dari Prodi Sastra Prancis ini berupa pelatihan kemampuan berbahasa Prancis bagi pengelola homestay di Desa Samiran, Kecamatan Selo. Program pengabdian ini merupakan implementasi keilmuan Prodi Sastra Prancis dalam mewujudkan visi dan misi UGM serta merupakan salah satu wujud nyata dari Tri Dharma Perguruan Tinggi, yaitu pengabdian kepada masyarakat.

Pelatihan bahasa Prancis ini mempersiapkan para pengelola dalam menyambut kunjungan wisatawan mancanegara yang berasal dari Prancis dan negara-negara francophone. Kunjungan wisatawan dari Prancis dan francophone pada wisata minat khusus, seperti mendaki gunung, akhir-akhir ini juga mengalami peningkatan. Hal tersebut dapat dilihat dari meningkatnya permintaan akan pemandu wisata berbahasa Prancis minat khusus ini pada biro-biro travel yang ada di Yogyakarta, terutama pada saat peak season. Salah satu tujuan para wisatawan tersebut adalah mendaki Gunung Merapi dan mereka memulai pendakian dari Selo yang sebelumnya menginap terlebih dahulu di homestay kawasan Desa Samiran.

Tujuan pelatihan ini adalah melatih kemampuan berbahasa Prancis yang berhubungan dengan percakapan sederhana di dalam homestay dan yang bertema 
gunung serta memperkenalkan Desa Samiran bagi komunitas masyarakat Prancis dan francophone. Adapun sasaran kegiatan ini adalah para pengelola homestay dan pelaku pariwisata di Desa Samiran, seperti pemilik kafe atau kedai, pemilik warung, penjual suvenir, dan lain-lain. Manfaat kegiatan ini adalah sebagai berikut. Pertama, menambah kompetensi komunikasi penduduk setempat dalam hal pelayanan tamu asing yang berdampak secara langsung dengan tingkat kepuasan wisatawan asing ketika berkunjung ke desa tersebut. Kedua, pengenalan Desa Samiran melalui website berbahasa Prancis sehingga dapat meningkatkan eksistensi desa ini. Di samping itu, pada era digital ini, promosi tempat wisata melalui website menjadi salah satu strategi marketing yang mudah menarik minat para wisatawan mancanegara untuk berkunjung ke Boyolali. Ketiga, pembuatan materi dan video bahasa Prancis pariwisata berbasis budaya lokal memiliki keunggulan jika dibandingkan dengan produk sejenis yang sudah beredar di masyarakat. Melalui produk ini, pembelajaran bahasa Prancis akan semakin mudah.

\section{Metode Pelaksanaan}

Metode pelaksanaan dalam kegiatan pengabdian ini terdiri atas persiapan, pelaksanaan, keberlanjutan, dan pelaporan. Tahap persiapan terdiri atas survei lapangan dan sosialisasi program kepada perangkat desa serta pihak yang terkait. Tahap pelaksanaan terdiri atas pembuatan bahan ajar, seleksi tutor, Training of Trainers (ToT) tutor, pelatihan bahasa Prancis, pembuatan video kegiatan, dan penerjemahan website. Tahap berikutnya adalah keberlanjutan program yang bertujuan memastikan bahwa program ini terus berjalan di lapangan meskipun tim program sudah tidak melakukan kegiatan di lokasi masyarakat sasaran. Tahap terakhir kegiatan ini adalah pelaporan hasil kegiatan yang meliputi pembuatan artikel serta luaran lainnya berupa video dan mengunggah hasil terjemahan pada website Desa Wisata Samiran.

\section{Hasil dan Pembahasan}

Kegiatan pengabdian kepada masyarakat ini mendapat dukungan dari pemerintah setempat, yaitu perangkat desa dan aparat setempat, serta dukungan yang penuh dari warga masyarakat Desa Samiran, Kecamatan Selo, Kabupaten Boyolali. Kegiatan ini tidak hanya melibatkan pemilik homestay dan pelaku pariwisata lainnya, tetapi juga melibatkan aparat desa. Kegiatan ini juga menjadi agenda kegiatan desa yang diketahui oleh aparat setempat, yaitu Kepolisian Sektor Kecamatan Selo, dengan kehadiran bapak kepala sektor di lokasi pengabdian, yaitu di salah satu homestay yang ada di desa tersebut.

Bagi penduduk setempat, kegiatan ini merupakan kegiatan yang menarik karena mereka dapat belajar bahasa Prancis dengan situasi yang menyenangkan. Hal ini dibuktikan dengan antusiasme warga setempat dalam mengikuti pelatihan. Mereka terlihat bersemangat dan pantang menyerah mengikuti apa yang dipaparkan oleh tutor melalui modul yang telah dipersiapkan sebelumnya oleh Prodi Sastra Prancis. Mereka mempraktikkan sapaan-sapaan dan kalimat-kalimat yang diajarkan oleh tutor serta mengikuti kegiatan ini dari awal hingga akhir acara tanpa merasa bosan. Pendekatan yang komunikatif dan kekeluargaan menjadikan para pembelajar percaya diri dan tidak malu meniru serta melafakan kalimat atau ungkapan dalam bahasa Prancis yang dapat 
mereka gunakan jika berkomunikasi dengan orang asing, baik yang berasal dari Prancis maupun dari negara francophone.

Kegiatan pengabdian pada masyarakat yang dilakukan ini dapat memberi nilai tambah bagi pelayanan wisatawan, khususnya yang berasal dari negara Prancis dan francophone, serta dapat meningkatkan jumlah wisatawan yang berkunjung dan bermalam di Desa Samiran. Pembuatan video kegiatan dan penerjemahan website diharapkan dapat ikut membantu meningkatkan jumlah wisatawan yang akan berkunjung dan singgah ke desa tersebut. Dampak dari peningkatan jumlah wisatawan tentu saja dapat meningkatkan taraf hidup dan perekonomian masyarakat setempat ke depannya.

Adapun detail kegiatan pengabdian kepada masyarakat ini adalah sebagai berikut.

\section{Tahap Persiapan Kegiatan}

Tahap persiapan diawali dengan survei lapangan pada 3 Juli 2018. Survei dilakukan untuk berdiskusi dengan perangkat dan pelaku pariwisata Desa Samiran, yaitu Bapak Mawardi selaku ketua koperasi pengelola homestay, tentang rencana program sekaligus untuk meminta izin pelaksanaan program. Dalam diskusi tersebut, tim pengabdian bersama perangkat desa menyepakati masyarakat sasaran program yang disesuaikan dengan kebutuhan di lapangan. Masyarakat sasaran program ini adalah warga atau masyarakat yang terlibat langsung dengan para wisatawan, seperti pemilik homestay, pemilik warung kelontong, pemilik warung kopi, dan pedagang suvenir, dengan sasaran utama adalah pemilik homestay. Berdasarkan hasil diskusi tersebut, tim pengabdian mulai merumuskan materi yang akan disampaikan pada pelaksanaan program, yaitu pada tahap pelatihan. Dengan adanya diskusi tersebut, tujuan program ini dapat berjalan sesuai dengan rencana dan tepat sasaran.

\section{Tabap Pelaksanaan Kegiatan}

Tahap selanjutnya adalah tahap pelaksanaan yang diawali dengan pembuatan bahan ajar yang disesuaikan dengan kebutuhan yang ada di masyarakat Desa Samiran sesuai dengan hasil diskusi pada tahap survei sebelumnya. Pembuatan bahan ajar ini dilakukan di Prodi Sastra Prancis, Fakultas Ilmu Budaya UGM dengan melibatkan mahasiswa dalam proses penyusunannya. Tujuan pelibatan mahasiswa ini selain untuk memberi pengalaman kepada mahasiswa juga untuk melatih mahasiswa dalam pembuatan materi pelatihan. Materi yang dibuat berupa materi percakapan sederhana seperti sapaan, perkenalan, percakapan ringan dalam bahasa Prancis yang kemungkinan dapat terjadi di sebuah homestay, ungkapan-ungkapan yang berhubungan dengan situasi dan alam pegunungan, percakapan jual beli, dan lain-lain.

Setelah disusun, bahan ajar disosialisasikan dalam kegiatan Training of Trainers (ToT) kepada mahasiswa yang akan menjadi tutor dalam pelaksanaan kegiatan ini. Tutor-tutor ini sebelumnya sudah melalui tahapan seleksi yang dilakukan di Prodi Sastra Prancis. ToT dilakukan untuk memberi bekal kepada mahasiswa tentang apa yang akan mereka lakukan di lapangan dan bagaimana cara menghadapi masyarakat ketika kegiatan ini dilakukan.

Tahap berikutnya adalah kegiatan pelatihan kemampuan berbahasa Prancis bagi pemilik homestay dan pelaku pariwisata di Desa Samiran, Kecamatan Selo, Kabupaten Boyolali yang dilaksanakan pada 9 September 2018 di Homestay Nuansa Baru milik Ketua 
RT 3 Desa Samiran. Pelatihan ini diikuti oleh 30 orang dan dihadiri oleh perangkat desa, yaitu Ketua RT 3, Bapak Ahmad Salib; Ketua Paguyuban, yaitu bapak Mawardi; dan dua orang polisi dari kepolisian sektor Selo. Pelatihan ini dibuka oleh ketua Prodi Sastra Prancis, yaitu Dr. Sajarwa, M.Hum. Bentuk pelatihan tidak menggunakan metode klasikal, tetapi metode pendekatan komunikatif personal yang berfokus pada kelompok-kelompok kecil. Kelompok-kelompok tersebut terdiri atas 2-3 orang dengan dipandu oleh seorang tutor dan disupervisi oleh beberapa dosen Prodi Sastra Prancis. Pada sesi ini, pembelajar diajarkan tentang percakapan dan ungkapan-ungkapan dalam bahasa Prancis serta mempraktikkannya langsung dengan tutor. Hal itu tidak mudah bagi pembelajar karena bahasa Prancis bukan bahasa yang sering mereka dengarkan dalam keseharian. Meskipun demikian, semangat dan motivasi yang besar dari para pembelajar serta pengaruh yang kuat dari para tutor menjadikan pelatihan ini dapat berjalan dengan lancar, sesuai dengan yang diharapkan.

Selama tahap pembelajaran, ada kelompok lain dari mahasiswa prodi yang juga melakukan kegiatan di Desa Samiran, yaitu membuat video dokumenter tentang program pelatihan ini. Mereka mendokumentasikan kegiatan ini dan juga kondisi salah satu desa wisata di Selo, Kabupaten Boyolali. Hasil dokumentasi akan dipublikasikan untuk mempromosikan desa wisata ini ke masyarakat umum hingga ke mancanegara, terutama ke negara-negara francophone.

Bagian akhir tahap ini adalah penerjemahan website desa wisata Samiran ke dalam bahasa Prancis. Selama ini, website desa wisata hanya menggunakan bahasa Indonesia dan bahasa Inggris. Dengan program ini, website desa wisata dapat lebih luas jangkauannya ke negara-negara francophone. Penerjemahan website ini dilakukan oleh mahasiswa Prodi Sastra Prancis dengan disupervisi oleh beberapa dosen yang terlibat dalam program ini. Bagi mahasiswa, penerjemahan ini merupakan ajang latihan dalam menerjemahkan website pariwisata, yang secara tidak langsung menerapkan hasil pembelajaran mata kuliah terjemahan.
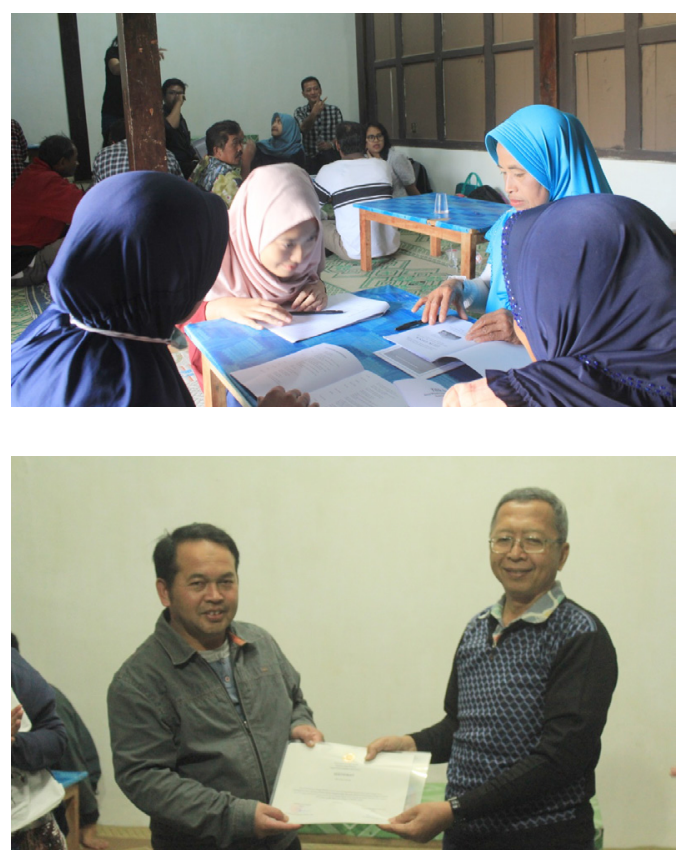

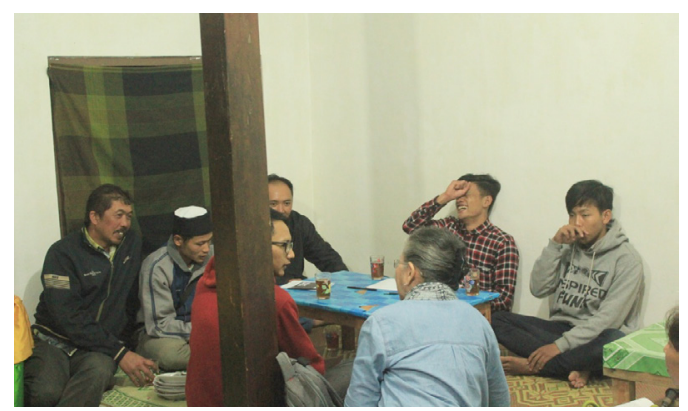

Gambar 1. Aktivitas Pelatihan Kemampuan Berbahasa Prancis bagi Pemilik Homestay dan Pelaku Pariwisata di Desa Samiran. 


\section{Tahap Keberlanjutan Kegiatan}

Program pengabdian kepada masyarakat dapat dianggap berhasil jika program yang itu dapat terus berlanjut meskipun sudah tidak ada pendampingan lagi. Oleh karena itu, perlu dibuat perencanaan untuk menjamin keberlangsungan program ini. Rencana yang dibuat oleh Prodi Sastra Prancis untuk menjamin kelanjutan program ini adalah melibatkan Himpunan Mahasiswa Sastra Prancis dengan memasukkan program pengabdian ini sebagai salah satu kegiatan rutin dan masuk dalam agenda kerja mereka. Dalam struktur organisasi HMSP ada divisi tersendiri yang menangani program pengabdian kepada masyarakat ini.

HMSP dapat berkunjung ke lapangan secara rutin, minimal sekali dalam setiap semester, dengan menggunakan dana pengabdian prodi untuk me-refresh kemampuan berbahasa Prancis mereka dan sekaligus mengader beberapa orang warga yang dianggap mampu serta dapat meneruskan program ini. Bagi mahasiswa, program ini dapat dijadikan sebagai ajang pembelajaran, baik pembelajaran yang berhubungan dengan kemampuan berbahasa Prancis mereka, pembelajaran untuk berinteraksi dengan masyarakat, pembelajaran dalam bidang pariwisata, maupun pembelajaran yang memberi pengalaman bagi mereka tentang dinamika yang ada di masyarakat. Dengan demikian, keberlanjutan program ini diharapkan dapat memberi manfaat bagi berbagai pihak, baik bagi masyarakat sesuai dengan tujuan pengabdian maupun mahasiswa sebagai ajang pembelajaran di luar kampus serta melatih kepekaan mereka dalam kehidupan bermasyarakat.

\section{Penutup}

Program pengabdian kepada masyarakat ini merupakan wujud kepedulian dan kepekaan Prodi Sastra Prancis, Fakultas Ilmu Budaya UGM dalam memberi solusi atas permasalahan yang ada di masyarakat terutama yang berhubungan dengan bidang pariwisata untuk meningkatkan kesejahteraan masyarakat desa wisata. Desa wisata merupakan salah satu alternatif penting di dalam pengembangan kepariwisataan yang langsung melibatkan masyarakat. Homestay yang disediakan dan ditawarkan dengan harga terjangkau dan suasana pedesaan yang khas di website atau situs-situs perjalanan wisata menjadi daya tarik sendiri, terutama bagi wisatawan asing. Di samping itu, kegiatan ini juga dapat memberi inspirasi kepada mahasiswa yang memiliki minat bekerja di sektor pariwisata yang notabene sangat potensial bagi mereka. Oleh karena itu, kegiatan seperti ini perlu terus dikembangkan, terutama di daerah wisata lain yang ada di sekitar Yogyakarta dan Jawa Tengah.

\section{Referensi}

Aditya, Ivan. (2017). Kedaulatan Rakyat, edisi 2 Juli. Diakses pada 11 Juli 2018 dari http://krjogja.com/web/news/read/36990/Kunjungan_Wisatawan_ke_S elo_ Melonjak.

Tiono, Arie, Rina. n.d. Homestay Merapi. Diakses pada 11 Juli 2017 dari https:// homestaymerapi.com/index.html. 